\title{
Reviews
}

\section{ANTARCTIC ICE SHELVES}

ICE SHELVES OF ANTARCTICA. Barkov, N. I. 1985. Rotterdam, Balkema. 262 p, illustrated, hard cover. ISBN 90-6191-435-3. £20.75.

This book was first published in Russian in 1971. At that time it represented a valuable contribution to the study of ice shelves - an almost exclusively Antarctic phenomenon. These large floating plates of ice, fed by the outward flow of grounded inland ice and by surface snow accumulation, are important and sensitive indications of the general health of the Antarctic Ice Sheet, and hence of climatic influences. In their own way they provide a restraining force on potentially unstable areas of ice such as that grounded below sea level in West Antarctica. Ice loss by bottom melting yields cold, high density water, important oceanographically in the production of Antarctic bottom water. The calving of large tabular icebergs is both spectacular and hazardous, providing the greatest single component of ice sheet ablation.

At the end of the 1960 s when this book was written, only very preliminary reconnaissance information was available on ice shelves. Some had been studied during the IGY and a primitive understanding had begun to emerge of their dynamics, thermodynamics, mass balance and role in climate-related processes. It is with this state-of-the-art of almost twenty years ago that this book is concerned. It should therefore be viewed as an historical summary of information available up to the 1970s.

Chapter 1 provides a brief historical review of the exploration of ice shelves. Chapter 2 examines factors relevant to the formation and continued existance of ice shelves (topographic, oceanographic, climatic). Chapter 3 describes morphologic features of ice shelves and Chapter 4 the mass balance of ice and snow to ice shelves. Chapter 5 is concerned with snow and ice structure, principally from bore-hole studies, and Chapters 6 and 7 with the thermal regime and motion of ice shelves, with theoretical treatments. Chapter 8 deals with the present state of ice shelves, their response to climate and past fluctuations, and the final chapter considers this classification.

The overriding weakness of this book is its age. The bulk of the references centre around 1961-1966. No account is taken of the enormous advances to ice shelf studies during the last fifteen or more years, particularly the results of the Ross Ice Shelf Project (surface glaciology, core drilling, observations beneath the ice shelf, associated oceanography, ice thickness and other geophysical measurements) and the substantial contribution from studies of the Amery Ice Shelf and the on-going Filchner-Ronne Ice Shelf Project. Concepts developed during the last decade of the role of ice shelves in the stability of the West Antarctic Ice Sheet, and the former extent of these ice masses, do not figure.

The illustrations, mainly reproduced from the Russian edition, vary in quality: the black and white photographs are totally unacceptable. There is no index, and the translation into English leaves much to be desired. Topographical errors abound and many place names or scientific terms have curious and inconsistent forms. In summary, it is good to have Barkov's book in English translation, but it is just fifteen years too late! (David J. Drewry, Scott Polar Research Institute, Lensfield Road, Cambridge CB2 1ER.) 